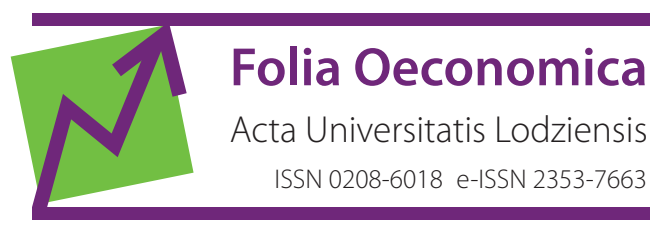

www.czasopisma.uni.lodz.pl/foe/

6(332) 2017

DOI: http://dx.doi.org/10.18778/0208-6018.332.08

\title{
Kamil Zawadzki
}

Uniwersytet Mikołaja Kopernika w Toruniu, Wydział Nauk Ekonomicznych i Zarządzania,

Katedra Gospodarowania Zasobami Pracy, kamil.zawadzki@umk.pl

\section{Monika Wojdyło}

Uniwersytet Mikołaja Kopernika w Toruniu, Wydział Nauk Ekonomicznych i Zarządzania,

Katedra Gospodarowania Zasobami Pracy, mwojdylo@umk.pl

\section{Zróżnicowanie tożsamości pierwotnej i wtórnej pracowników małych przedsiębiorstw w Polsce}

Streszczenie: Celem artykułu jest analiza zróżnicowania zatrudnienia ze względu na wybrane elementy tożsamości pierwotnej i wtórnej w organizacjach w Polsce zatrudniających od 10 do 40 pracowników. Dane o ponad 146 tys. zatrudnionych w 7,2 tys. małych zakładów pracy zostały pozyskane ze sprawozdania o strukturze wynagrodzeń według zawodów Z-12. Przeprowadzone badania pozwoliły wskazać, że wśród objętych badaniem pracowników małych przedsiębiorstw w Polsce występuje znaczne zróżnicowanie tożsamości, szczególnie w jej wtórnym wymiarze. Zidentyfikowano także istotną dywersyfikację tego zróżnicowania w odniesieniu do firm o różnej wielkości i działających w różnych branżach. Wykazano również, że instrumenty zarządzania różnorodnością mogą poprawić funkcjonowanie małych przedsiębiorstw w Polsce.

Słowa kluczowe: zarządzanie różnorodnością, małe przedsiębiorstwa, zróżnicowanie zatrudnienia JEL: M14, M54, J82, J24 


\section{Wprowadzenie}

Zarządzanie zasobami ludzkimi w małych zakładach pracy jest uwarunkowane ich specyfiką. Z jednej strony kształtują się w nich zalążki struktur organizacyjnych, jednak $z$ drugiej podmioty te są jeszcze zbyt małe na tworzenie wyspecjalizowanych komórek personalnych dbających profesjonalnie o sprawne gospodarowanie posiadanym kapitałem ludzkim. W krajowej literaturze przedmiotu rzadko analizowane są wyłącznie małe podmioty (tj. zatrudniające od 10 do 49 osób). Zwykle określa się je mianem małych i średnich przedsiębiorstw (MŚP), razem z mikroprzedsiębiorstwami i firmami zatrudniającymi od 50 do 249 osób. W tych analizach podnosi się kwestie budowania efektywnego systemu wynagrodzeń w MŚP (Ziemba, Świerszczak, 2011), skutecznego motywowania pracowników tych podmiotów (Kawka, 2010) i potrzeb rozwojowych ich kadry (Rak, 2015). W ramach problematyki zarządzania różnorodnością w podmiotach tej wielkości można wskazać prowadzenie badań nad zarządzaniem wiekiem (Szaban, 2013) i funkcjonowaniem kobiet w organizacji (Szepelska, 2013).

Tymczasem warto przyjrzeć się cechom małych przedsiębiorstw i wynikającym z ich specyfiki implikacjom dla zarządzania zasobami ludzkimi. W 2015 roku było ich w Polsce 56 713, co stanowiło 3\% wszystkich przedsiębiorstw w kraju i przekraczało trzykrotnie liczbę firm, w których pracowało co najmniej 50 osób (GUS, 2016). W małych firmach pracowało niemal 1,2 mln osób, a 1,073 mln było w nich zatrudnionych. Stanowią one ważną część rynku pracy i całej gospodarki, generując przychody odpowiadające $60 \%$ przychodów uzyskanych przez mikroprzedsiębiorstwa, których jest ponad trzydzieści razy więcej (1,8 mln).

Innowacje w zakresie zarządzania zasobami ludzkimi zwykle w pierwszej kolejności implementowane są przez korporacje międzynarodowe i konkurujące z nimi duże podmioty krajowe. Dopiero w następnej kolejności, gdy rozwiązania są już ugruntowane, bywają wdrażane przez mniejsze firmy. W polskich warunkach taką jeszcze nierozpowszechnioną wśród małych podmiotów ideą jest zarządzanie różnorodnością (diversity management), postrzegane przez niektórych badaczy jako nowy paradygmat podejścia do człowieka w organizacji, po administrowaniu kadrami, zarządzaniu zasobami ludzkimi oraz zarządzaniu kapitałem ludzkim (Wziątek-Staśko, 2012: 24). O ile duzi pracodawcy, a w szczególności przedsiębiorstwa międzynarodowe, od dłuższego czasu stoją przed wyzwaniami sprawnego zarządzania zespołami pracowniczymi znacznie zróżnicowanymi nie tylko ze względu na wiek, płeć czy posiadane kwalifikacje, ale także kulturowo, o tyle mniejsi przedsiębiorcy korzystali do tej pory z możliwości bardziej homogenicznego kształtowania zasobów pracy w swoich zespołach.

Ta era jednak nieuchronnie się kończy. Przed polskimi przedsiębiorstwami, w szczególności małymi i średnimi, stają wyzwania niedoboru siły roboczej. Wynika to zarówno z ograniczonej możliwości konkurowania z korporacjami o spe- 
cjalistów za pomocą oferowanych warunków finansowych, jak i z kurczącej się puli dostępnych rodzimych zasobów pracy. Jest to spowodowane malejącą aktywnością zawodową osób w wieku produkcyjnym, niskim wiekiem emerytalnym w Polsce, rozbudowanymi transferami socjalnymi, emigracją zarobkową oraz wciąż dużym zainteresowaniem kształceniem formalnym na poziomie studiów wyższych, co opóźnia decyzję młodzieży o wejściu na rynek pracy. Z całą pewnością wymusi to sięganie również przez MŚP po coraz bardziej zróżnicowane zasoby pracy i w konsekwencji przysporzy nowych wyzwań zarządzającym tymi podmiotami.

Punktem wyjścia do planowania przemian strukturalnych zatrudnienia w małych firmach powinno być rozpoznanie obszarów, w których może to być szczególnie trudne. Pojawia się więc potrzeba empirycznego zbadania aktualnego zróżnicowania tożsamości zatrudnionych w małych przedsiębiorstwach w Polsce.

Celem badań, których wyniki zaprezentowano w niniejszym artykule, było rozpoznanie zróżnicowania zatrudnienia w organizacjach liczących od 10 do 40 pracowników, ze względu na wybrane elementy tożsamości pierwotnej i wtórnej personelu. Skupiono się na czterech wyznacznikach różnorodności: płci, wieku, poziomie wykształcenia oraz doświadczeniu zawodowym. Sformułowano hipotezę, że objęte badaniem małe przedsiębiorstwa w Polsce są podmiotami w znacznym stopniu homogenicznymi w zakresie analizowanych wyznaczników zróżnicowania tożsamości pierwotnej i wtórnej.

W dalszej części artykułu wskazano zakres i znaczenie tożsamości pierwotnej i wtórnej pracowników w organizacjach. Następnie zaprezentowano wyniki przeprowadzonych badań dotyczących zróżnicowania zatrudnionych w przedsiębiorstwach liczących od 10 do 40 pracowników ze względu na ich tożsamość pierwotną i wtórną oraz sformułowano wnioski.

\section{Tożsamość pierwotna i wtórna}

Pojęcie tożsamości pierwotnej i wtórnej pracowników jest związane bezpośrednio z koncepcją zarządzania różnorodnością. Podejście to wyewoluowało w USA na przełomie lat osiemdziesiątych i dziewięćdziesiątych XX wieku w rezultacie obserwacji ówczesnych przemian demograficznych na amerykańskim rynku pracy (Johnston, Packer, 1987). Korzeni zarządzania różnorodnością należy szukać na gruncie polityki równości (equity policies) - koncepcji znanej w USA i Europie Zachodniej już dwie dekady wcześniej. Podkreślała ona znaczenie równych szans na rynku pracy osób różniących się wiekiem, płcią, rasą, narodowością, wyznaniem czy orientacją seksualną i potrzebę przeciwdziałania dyskryminacji pracowników (Kirton, Greene, 2010: 2-3).

Różnorodność nie tylko samej organizacji, ale i otoczenia, w którym ona działa - dostawców, klientów, podmiotów państwowych, z którymi firma musi wcho- 
dzić w interakcje - powinno się dziś traktować jako szansę na poprawę efektywności jej funkcjonowania (Urbaniak, 2014: 63-64). Z perspektywy zarządzania zasobami ludzkimi w firmie różnorodność należy natomiast odnieść do niejednolitości szeregu wrodzonych, nabytych oraz specyficznych dla aktualnej roli zawodowej cech pracowników danej organizacji. Nawiązując do trzech wymiarów modelu tożsamości osobistej (Arredondo, 1996: 29-30), cechy te można sklasyfikować jako elementy tożsamości pierwotnej, wtórnej i organizacyjnej (Walczak, 2011: 11-12).

Tożsamość pierwotna obejmuje niezmienne, najczęściej wrodzone cechy pracownika, odnoszące się do jego płci, wieku, rasy, języka ojczystego, osobowości, niepełnosprawności, narodowości, orientacji seksualnej, pochodzenia itp.

Elementy tożsamości wtórnej dotyczą cech modyfikowalnych, mogących w dłuższym okresie ulegać zmianom, ale niezwiązanych bezpośrednio lub związanych tylko w pewnym zakresie z funkcjonowaniem danego pracownika w organizacji. Dotyczyć mogą między innymi jego miejsca zamieszkania, statusu materialnego, dochodów, wykształcenia i innych kwalifikacji formalnych, doświadczenia zawodowego, stanu cywilnego, posiadania dzieci, wyznania, wyglądu, zwyczajów, zainteresowań itp.

Tożsamość organizacyjną wyznacza z kolei miejsce w strukturze organizacyjnej i hierarchii służbowej pracownika, charakter wykonywanej przez niego pracy, przysługujący mu zakres uprawnień decyzyjnych, posiadane w danej instytucji uprawnienia, prestiż z tytułu pełnionej funkcji zawodowej, dodatkowe przywileje pracownicze, stawki otrzymywanego $\mathrm{w}$ danej firmie wynagrodzenia, forma nawiązania stosunku pracy, staż pracy w danej organizacji, zakres wykonywanych zadań, obowiązków i odpowiedzialności, a także szczególne prawa gwarantujące ochronę przed zwolnieniem itp.

\section{Zróżnicowanie zatrudnienia w małych przedsiębiorstwach w Polsce - badania empiryczne}

\subsection{Wykorzystane dane i dobór próby}

Do badania wykorzystano dane pochodzące ze sprawozdania GUS o strukturze wynagrodzeń według zawodów za 2012 rok (Z-12). Zawierało ono raportowane przez pracodawców informacje dotyczące osób przez nich zatrudnionych. Podmioty biorące udział w badaniu były losowane osobno dla każdej zbiorowości - rozumianej jako zbiór zakładów pracy określony przez sekcję PKD 2007 oraz sektor własności. Następnie w ramach każdej zbiorowości zakłady pracy były grupowane warstwowo według liczby pracujących. $Z$ każdej warstwy losowane były okre- 
ślone frakcje podmiotów do badania. Szczegółowy opis procedury doboru próby pracodawców można znaleźć w raporcie GUS (2014).

Z wylosowanej próby pracodawców w kolejnym kroku dobrani zostali pracownicy. W odniesieniu do podmiotów zatrudniających do 40 osób badaniem objęto wszystkich zatrudnionych w tych jednostkach. Za zatrudnionych w wylosowanych do badania podmiotach uznano pracowników, którzy byli zatrudnieni na podstawie stosunku pracy i znajdowali się w ewidencji jednostki w okresie od 1 do 31 października 2012 roku w pełnym lub niepełnym wymiarze czasu obowiązującym w danym zakładzie pracy lub na danym stanowisku. Wykluczono jednocześnie osoby, które w październiku 2012 roku były na zwolnieniach lekarskich, urlopach wypoczynkowych, urlopach bezpłatnych, profilaktycznych i dla poratowania zdrowia, urlopach macierzyńskich lub wychowawczych, na emeryturze i jednocześnie pracowały w jednostce sprawozdawczej. Nie ujęto także wykonujących pracę na podstawie umowy cywilnoprawnej, umowy o pracę nakładczą, kontraktu menedżerskiego, w formie samozatrudnienia, pracy tymczasowej lub weekendowej, umowy agencyjnej. Ponadto wykluczono zatrudnionych w ramach prac interwencyjnych i robót publicznych, uczestniczących w grupach roboczych zorganizowanych przez inne jednostki i oddelegowanych do pracy w jednostce sprawozdawczej oraz praktykantów. Jeżeli liczba zatrudnionych spełniających tak postawione warunki nie przekraczała czterdziestu osób, to badaniem obejmowano wszystkich zatrudnionych w danym podmiocie. Właśnie ze względu na tę granicę - wyznaczoną przez GUS dla przeprowadzania w wylosowanych przedsiębiorstwach badań pełnych - w wykorzystanej do niniejszych analiz próbie ograniczono się do firm zatrudniających od 10 do 40 osób. W znacznej części próba ta pokrywa się z powszechnie wykorzystywaną w statystyce publicznej definicją małych przedsiębiorstw, która za takie uznaje podmioty zatrudniające od 10 do 49 osób. Mimo znacznej przystawalności obu zbiorów - warstwy najmniejszych instytucji z badania GUS Z-12 i podmiotów określanych jako „małe przedsiębiorstwa" - należy podkreślić, że prezentowane w artykule wyniki nie uwzględniają zjawisk dotyczących zróżnicowania tożsamości w jednostkach zatrudniających od 41 do 49 osób. W konsekwencji prezentowane wyniki mogą nie być w pełni reprezentatywne dla grupy „małych przedsiębiorstw”.

Spośród firm wylosowanych do sprawozdawczości przez GUS w 2012 roku na potrzeby przeprowadzenia analiz przedstawionych w niniejszym artykule wyodrębniono 7197 podmiotów zatrudniających od 10 do 40 osób. Łącznie były w nich zatrudnione 146804 osoby, które weszły w skład próby badawczej wykorzystanej do określenia zróżnicowania tożsamości pierwotnej i wtórnej. Do obliczeń wykorzystano programy statystyczne Gretl (wersja 1.9.92) i Microsoft Excel 2016. 


\subsection{Wyniki badań empirycznych}

\subsubsection{Zróżnicowanie małych przedsiębiorstw według płci zatrudnionych}

W objętych badaniem małych przedsiębiorstwach zatrudnionych było łącznie 84,7 tys. kobiet, co stanowiło 57,7\% ogółu próby zatrudnionych. W 58,7\% firm i instytucji wśród zatrudnionych przeważały kobiety. $Z$ kolei w $6,1 \%$ badanych przedsiębiorstw nie było w ogóle kobiet zatrudnionych na podstawie umowy o pracę, a w 4,4\% instytucji zatrudnione były wyłącznie kobiety.

Analizując strukturę zatrudnienia według płci, w przedsiębiorstwach zatrudniających od 10 do 40 osób widać wyraźną pozytywną korelację między liczbą zatrudnionych ogółem w danej instytucji a liczbą zatrudnionych tam kobiet. Tak więc, jeśli chodzi o małe firmy, im podmiot jest większy, tym bardziej skłonny jest zatrudniać kobiety.

Ponadto w kontekście zarządzania różnorodnością i równych szans rozwoju zawodowego warto odnotować, że prawie 6,8 tys. kobiet w badanych zakładach pracy zajmowało stanowiska kierownicze'. Stanowiły one jedynie $8 \%$ wszystkich zatrudnionych w badanych podmiotach kobiet, podczas gdy wśród mężczyzn udział ten wynosił 10\%. Świadczy to o niewielkiej niedoreprezentacji kobiet wśród zatrudnionych na stanowiskach kierowniczych.

W zależności od branży, do której należy mały pracodawca, struktura zatrudnienia ze względu na płeć osób tam zatrudnionych jest bardzo zróżnicowana (tab. 1).

Tabela 1. Udział kobiet w zatrudnieniu według sekcji PKD (\%)

\begin{tabular}{|l|l|c|}
\hline Sekcja A & Rolnictwo, leśnictwo, łowiectwo i rybactwo & 24,3 \\
\hline Sekcja B & Górnictwo i wydobywanie & 19,9 \\
\hline Sekcja C & Przetwórstwo przemysłowe & 32,5 \\
\hline Sekcja D & $\begin{array}{l}\text { Wytwarzanie i zaopatrywanie w energię elektryczną, gaz, parę wodną, } \\
\text { gorącą wodę i powietrze do układów klimatyzacyjnych }\end{array}$ & 18,8 \\
\hline Sekcja E & $\begin{array}{l}\text { Dostawa wody; gospodarowanie ściekami i odpadami oraz działalność } \\
\text { związana z rekultywacją }\end{array}$ & 22,0 \\
\hline Sekcja F & Budownictwo & 12,0 \\
\hline Sekcja G & $\begin{array}{l}\text { Handel hurtowy i detaliczny; naprawa pojazdów samochodowych, włączając } \\
\text { motocykle }\end{array}$ & 48,3 \\
\hline Sekcja H & Transport i gospodarka magazynowa & 16,1 \\
\hline Sekcja I & Działalność związana z zakwaterowaniem i usługami gastronomicznymi & 68,2 \\
\hline Sekcja J & Informacja i komunikacja & 38,6 \\
\hline Sekcja K & Działalność finansowa i ubezpieczeniowa & 74,9 \\
\hline Sekcja L & Działalność związana z obsługą rynku nieruchomości & 55,3 \\
\hline Sekcja M & Działalność profesjonalna, naukowa i techniczna & 57,4 \\
\hline
\end{tabular}

${ }^{1}$ Rozumiane jako przynależność zawodu wykonywanego przez badanego do pierwszej grupy wielkiej Klasyfikacji Zawodów i Specjalności. 


\begin{tabular}{|l|l|c|}
\hline Sekcja N & Działalność w zakresie usług administrowania i działalność wspierająca & 44,4 \\
\hline Sekcja O & $\begin{array}{l}\text { Administracja publiczna i obrona narodowa; obowiązkowe zabezpieczenia } \\
\text { społeczne }\end{array}$ & 65,0 \\
\hline Sekcja P & Edukacja & 82,9 \\
\hline Sekcja Q & Opieka zdrowotna i pomoc społeczna & 85,6 \\
\hline Sekcja R & Działalność związana z kulturą, rozrywką i rekreacją & 63,8 \\
\hline Sekcja S & Pozostała działalność usługowa & 53,2 \\
\hline
\end{tabular}

Źródło: obliczenia własne

Branże, w których struktura zatrudnienia była niemal parytetowa, to: handel hurtowy i detaliczny, obsługa rynku nieruchomości, działalność profesjonalna, naukowa i techniczna, administracja oraz pozostała działalność usługowa. Najbardziej sfeminizowane okazały się opieka zdrowotna i pomoc społeczna oraz edukacja. Wyraźną dominację zatrudnienia kobiet można było wskazać także w firmach prowadzących działalność finansową i ubezpieczeniową oraz związaną z zakwaterowaniem i usługami gastronomicznymi. Z kolei zdominowanymi przez mężczyzn sektorami działalności małych przedsiębiorstw były: budownictwo, górnictwo, dostawa wody, gospodarowanie ściekami i odpadami, a także rolnictwo i leśnictwo.

\subsubsection{Zróżnicowanie małych przedsiębiorstw według wieku zatrudnionych}

W podmiotach objętych badaniem zatrudniano ponad 25,9 tys. pracowników w wieku do 29 lat, co stanowiło 17,7\% ogółu badanych. Analizowane firmy zatrudniały 41,7 tys. osób w wieku 30-39 lat, to jest 28,4\% badanych. Z kolei ponad jedną czwartą stanowili czterdziestolatkowie - 38,6 tys. (26,3\%), a także zatrudnieni mający co najmniej 50 lat - 40,4 tys. osób (27,6\%).

Analizując strukturę zatrudnionych według wieku, w małych podmiotach można dostrzec istotną reprezentację osób w każdej grupie wiekowej między 25. a 55. rokiem życia. Rozkład ma charakter bimodalny, odzwierciedlający wyże demograficzne na rynku pracy. Można także zaobserwować powolne wchodzenie na rynek pracy osób do lat 24, a także szybką dezaktywizację pracowników jeszcze przed osiągnięciem przez nich wieku emerytalnego.

Średni wiek pracownika zatrudnionego w małym przedsiębiorstwie w Polsce w 2012 roku wyniósł 41,2 lata. Informację tę trudno jednak interpretować z perspektywy zarządzania różnorodnością w poszczególnych zespołach pracowniczych. U pracodawców średnia wieku zatrudnionych wahała się bowiem od 21,8 do 60,1 lat. Najmłodsze zatrudnione osoby miały 16 lat, a najstarsze 73 lata, przy czym aż 90\% zatrudnionych stanowiły osoby w wieku 25-58 lat. Współczynnik zmienności dla zmiennej, ,wiek” w całej badanej populacji wyniósł 0,26, co należy uznać za wynik świadczący raczej o umiarkowanym lub wręcz niewielkim rozproszeniu tej cechy wokół średniej. To niewielkie zróżnicowanie ze względu 
na wiek pracowników firm liczących od 10 do 40 zatrudnionych potwierdza również obecność wśród badanych podmiotów takich pracodawców, u których najstarsi zatrudnieni mają zaledwie 25 lat, a także takich, których najmłodszy pracownik skończył już 51 lat. Ponadto stwierdzono pozytywną korelację między wielkością danego pracodawcy a średnim wiekiem osób u niego zatrudnionych $($ Pearson $=0,14)$, pozytywną zależność między wielkością zatrudnienia a wiekiem najstarszego zatrudnionego $(\mathrm{P}=0,29)$, a także ujemną relację między wielkością zatrudnienia w danym podmiocie a wiekiem najmłodszego zatrudnionego $(\mathrm{P}=-0,149)$.

Stwierdzono także, że w większości branż - niezależnie od średniej wieku w danej branży - zmienność tej cechy kształtuje się na poziomie zbliżonym do średniej w ogóle małych firm (tab. 2).

Tabela 2. Współczynnik zmienności wieku zatrudnionych według sekcji PKD

\begin{tabular}{|l|l|c|}
\hline Sekcja A & Rolnictwo, leśnictwo, łowiectwo i rybactwo & 0,27 \\
\hline Sekcja B & Górnictwo i wydobywanie & 0,25 \\
\hline Sekcja C & Przetwórstwo przemysłowe & 0,27 \\
\hline Sekcja D & $\begin{array}{l}\text { Wytwarzanie i zaopatrywanie w energię elektryczną, gaz, parę wodną, } \\
\text { gorącą wodę i powietrze do układów klimatyzacyjnch }\end{array}$ & 0,20 \\
\hline Sekcja E & $\begin{array}{l}\text { Dostawa wody; gospodarowanie ściekami i odpadami oraz działalność } \\
\text { związana z rekultywacją }\end{array}$ & 0,24 \\
\hline Sekcja F & Budownictwo & 0,29 \\
\hline Sekcja G & $\begin{array}{l}\text { Handel hurtowy i detaliczny; naprawa pojazdów samochodowych, włączając } \\
\text { motocykle }\end{array}$ & 0,28 \\
\hline Sekcja H & Transport i gospodarka magazynowa & 0,28 \\
\hline Sekcja I & Działalność związana z zakwaterowaniem i usługami gastronomicznymi & 0,31 \\
\hline Sekcja J & Informacja i komunikacja & 0,28 \\
\hline Sekcja K & Działalność finansowa i ubezpieczeniowa & 0,25 \\
\hline Sekcja L & Działalność związana z obsługą rynku nieruchomości & 0,24 \\
\hline Sekcja M & Działalność profesjonalna, naukowa i techniczna & 0,29 \\
\hline Sekcja N & Działalność w zakresie usług administrowania i działalność wspierająca & 0,29 \\
\hline Sekcja O & $\begin{array}{l}\text { Administracja publiczna i obrona narodowa; obowiązkowe zabezpieczenia } \\
\text { społeczne }\end{array}$ & 0,25 \\
\hline Sekcja P & Edukacja & 0,22 \\
\hline Sekcja Q & Opieka zdrowotna i pomoc społeczna & 0,24 \\
\hline Sekcja R & Działalność związana z kulturą, rozrywką i rekreacją & 0,25 \\
\hline Sekcja S & Pozostała działalność usługowa & 0,30 \\
\hline
\end{tabular}

Źródło: obliczenia własne

Wyraźniejszymi odstępstwami są tu jedynie mniej zróżnicowana wiekowo sekcja D (Wytwarzanie i zaopatrywanie w energię elektryczną, gaz, parę wodną, gorącą wodę i powietrze do układów klimatyzacyjnych) i sekcja P (Edukacja). Największe zróżnicowanie ze względu na wiek zaobserwowano w przedsiębior- 
stwach działających w sekcji I (Usługi gastronomiczne i hotelarstwo) oraz sekcji S (Pozostała działalność usługowa).

\subsubsection{Zróżnicowanie małych przedsiębiorstw według poziomu wykształcenia zatrudnionych}

W sprawozdaniu Z-12 badani pracodawcy sklasyfikowali zatrudnionych u siebie pracowników według jednego z dziewięciu poziomów wykształcenia: wyższe ze stopniem naukowym co najmniej doktora, wyższe z tytułem magistra, lekarza lub równorzędnym, wyższe z tytułem inżyniera, licencjata, dyplomowanego ekonomisty lub równorzędnym, policealne, średnie zawodowe, średnie ogólnokształcące, zasadnicze zawodowe, gimnazjalne oraz podstawowe i niepełne podstawowe. Na 7,2 tys. przebadanych firm jedynie w $23 \%$ występują maksymalnie trzy z tych poziomów, w 52\% cztery lub pięć różnych poziomów wykształcenia, a aż w co czwartym zatrudnione osoby legitymują się sześcioma, siedmioma lub ośmioma różnymi poziomami wykształcenia formalnego (wykres 1).

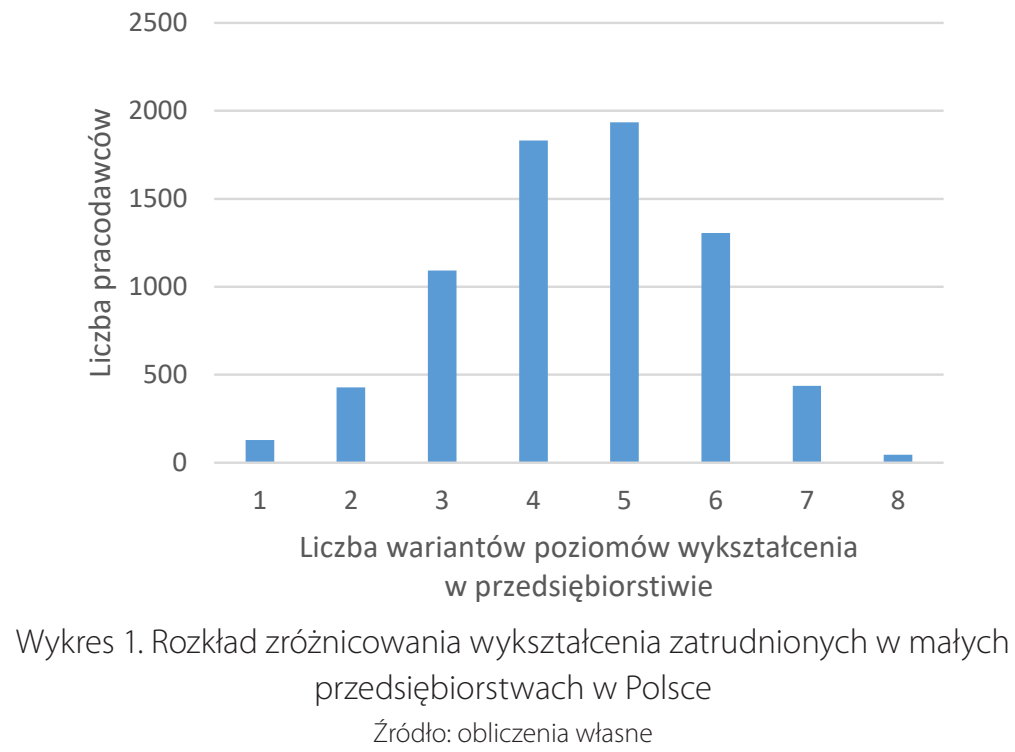

Uzyskane wyniki wskazują, że im większa firma, tym większe zróżnicowanie zatrudnionych ze względu na poziom wykształcenia. Biorąc jednak pod uwagę fakt, że analizie poddano jedynie małe firmy, zatrudniające nie więcej niż 40 osób, oznacza to, że jeśli chodzi o jeden z najważniejszych elementów tożsamości wtórnej - poziom formalnego wykształcenia - są to podmioty bardzo silne zróżnicowane. 


\subsubsection{Zróżnicowanie małych przedsiębiorstw ze względu na doświadczenie zawodowe zatrudnionych}

Średni staż pracy ogółem wśród pracowników badanych firm wyniósł 17 lat, a mediana 15 lat. Rozkład tej cechy jest asymetryczny. Co ciekawe, wartość maksymalna dla tej zmiennej osiągnęła poziom aż 53 lat ogólnego stażu pracy. Współczynnik zmienności w całym rozkładzie zmiennej wyniósł 0,69 , świadcząc o dużym zróżnicowaniu całkowitego doświadczenia zawodowego wśród badanych. Mimo silnego skorelowania $\mathrm{z}$ wiekiem zatrudnionego można zauważyć wyraźne różnice między tymi dwiema zmiennymi, szczególnie w odniesieniu do osób o krótkim stażu pracy, których jest w populacji najwięcej.

Zróżnicowanie doświadczenia zawodowego mierzonego ogólnym stażem pracy osób zatrudnionych w małych przedsiębiorstwach działających w różnych branżach gospodarki jest znaczne (tab. 3).

Tabela 3. Współczynnik zmienności stażu zatrudnionych według sekcji PKD pracodawcy

\begin{tabular}{|l|l|c|}
\hline Sekcja A & Rolnictwo, leśnictwo, łowiectwo i rybactwo & 0,63 \\
\hline Sekcja B & Górnictwo i wydobywanie & 0,59 \\
\hline Sekcja C & Przetwórstwo przemysłowe & 0,72 \\
\hline Sekcja D & $\begin{array}{l}\text { Wytwarzanie i zaopatrywanie w energię elektryczną, gaz, parę wodną, } \\
\text { gorącą wodę i powietrze do układów klimatyzacyjnych }\end{array}$ & 0,47 \\
\hline Sekcja E & $\begin{array}{l}\text { Dostawa wody; gospodarowanie ściekami i odpadami oraz działalnośćc } \\
\text { związana z rekultywacją }\end{array}$ & 0,55 \\
\hline Sekcja F & Budownictwo & 0,81 \\
\hline Sekcja G & $\begin{array}{l}\text { Handel hurtowy i detaliczny; naprawa pojazdów samochodowych, włączając } \\
\text { motocykle }\end{array}$ & 0,80 \\
\hline Sekcja H & Transport i gospodarka magazynowa & 0,82 \\
\hline Sekcja I & Działalność związana z zakwaterowaniem i usługami gastronomicznymi & 0,89 \\
\hline Sekcja J & Informacja i komunikacja & 0,91 \\
\hline Sekcja K & Działalność finansowa i ubezpieczeniowa & 0,66 \\
\hline Sekcja L & Działalność związana z obsługą rynku nieruchomości & 0,57 \\
\hline Sekcja M & Działalność profesjonalna, naukowa i techniczna & 0,90 \\
\hline Sekcja N & Działalność w zakresie usług administrowania i działalność wspierająca & 0,79 \\
\hline Sekcja O & $\begin{array}{l}\text { Administracja publiczna i obrona narodowa; obowiązkowe zabezpieczenia } \\
\text { społeczne }\end{array}$ & 0,59 \\
\hline Sekcja P & Edukacja & 0,58 \\
\hline Sekcja Q & Opieka zdrowotna i pomoc społeczna & 0,60 \\
\hline Sekcja R & Działalność związana z kulturą, rozrywką i rekreacją & 0,62 \\
\hline Sekcja S & Pozostała działalność usługowa & 0,84 \\
\hline
\end{tabular}

Źródło: obliczenia własne

Zróżnicowanie tej cechy wśród zatrudnionych w usługach gastronomicznych, zakwaterowaniu, informacji i komunikacji oraz działalności profesjonalnej, nauko- 
wej i technicznej (sekcje I, J i M) jest bardzo duże, o czym świadczy odchylenie standardowe niemal równe średniej w danej sekcji. Najbardziej jednolite pod tym względem są branże związane z energetyką (sekcja D), gospodarką wodną i kanalizacyjną (sekcja E) oraz obsługą rynku nieruchomości (sekcja L).

\section{Wnioski}

Przedstawioną we wprowadzeniu hipotezę badawczą zweryfikowano negatywnie: badane małe przedsiębiorstwa w Polsce są w znacznym stopniu heterogeniczne ze względu na analizowane elementy tożsamości ich pracowników. Ponadto zidentyfikowano istotną dywersyfikację tego zróżnicowania w firmach o różnej wielkości i działających w różnych branżach. Można zatem stwierdzić, że instrumenty zarządzania różnorodnością byłyby nie tylko pomocne, ale wręcz niezbędne w znacznej części małych przedsiębiorstw w Polsce.

Potwierdzają to wyniki analiz przeprowadzonych dla każdego z założonych wyznaczników różnicujących tożsamość pierwotną i wtórną osób zatrudnionych w małych przedsiębiorstwach. Choć w prawie $60 \%$ przebadanych podmiotów kobiety dominowały wśród zatrudnionych, trzeba zwrócić uwagę, że udział zatrudnionych kobiet jest wyraźnie mniejszy w najmniejszych spośród badanych przedsiębiorstw. To w nich z jednej strony zarządzanie różnorodnością ze względu na płeć może być mniej potrzebne, z drugiej jednak strony, gdy w niedalekiej przyszłości nastąpi konieczność większej dywersyfikacji zasobów pracy, najtrudniej będzie je wprowadzić. Warto także promować w małych przedsiębiorstwach równy dostęp kobiet do stanowisk kierowniczych. Udział kobiet na stanowiskach kierowniczych wśród ogółu kobiet zatrudnionych w małych podmiotach jest o $22 \%$ mniejszy niż analogiczny odsetek mężczyzn. Ponadto struktura zatrudnienia ze względu na płeć w małych firmach w Polsce bardzo się różni w zależności od branży. W równym dostępie do zatrudnienia obu płci przodują handel hurtowy i detaliczny, obsługa rynku nieruchomości, działalność profesjonalna, naukowa i techniczna, administracja oraz pozostała działalność usługowa.

W małych przedsiębiorstwach w Polsce nie ma jednej dominującej grupy wiekowej: udział trzydziesto-, czterdziesto- i pięćdziesięciolatków w zatrudnieniu jest bardzo zbliżony. Nie oznacza to jednak bardzo silnej dywersyfikacji kadry poszczególnych przedsiębiorstw ze względu na wiek. Analizowane dane wskazywały, że małe firmy zatrudniały osoby zwykle niewiele różniące się od siebie wiekiem. Dodatkowo wykazano, że większe spośród badanych podmiotów były bardziej skłonne zatrudniać osoby starsze niż podmioty mniejsze. Z jednej strony widać zatem, że mały biznes jest otwarty na zatrudnianie osób w każdym wieku, a z drugiej, że poszczególne organizacje raczej niechętnie dobierają współpracowników z różnych pokoleń. W sytuacji niedoboru pracowników i konieczno- 
ści większej niż do tej pory dywersyfikacji zasobów pracy narzędzia zarządzania wiekiem byłyby zatem wskazane w tych podmiotach. Ze względu na to, że branża nie była determinantą silnie różnicującą dywersyfikację zatrudnionych według wieku, niniejszy postulat dotyczy wszystkich sekcji działalności małych przedsiębiorstw.

W odniesieniu do wybranych wyznaczników tożsamości wtórnej osób zatrudnionych w małych przedsiębiorstwach, odnoszących się do ich wykształcenia i stażu pracy, wyniki przeprowadzonych badań wskazują, że w co czwartym badanym małym przedsiębiorstwie współpracownicy legitymują się ponad pięcioma typami poziomów wykształcenia. Oznacza to koegzystencję zawodową osób z wykształceniem wyższym, średnim i poniżej średniego. Presję na implementację narzędzi zarządzania różnorodnością ze względu na ten element tożsamości najsilniej widać wśród firm zatrudniających więcej osób. Natomiast współpracę osób o najbardziej zróżnicowanym stażu pracy widać wśród zatrudnionych w takich branżach, jak usługi gastronomiczne i zakwaterowanie, informacja i komunikacja oraz działalność profesjonalna, naukowa i techniczna.

\section{Bibliografia}

Arredondo P. (1996), Successful Diversity Management Initiatives: A blueprint for planning and implementation, Sage Publications Ltd., London.

GUS (2014), Struktura wynagrodzeń wedtug zawodów w październiku 2012 r., Warszawa.

GUS (2016), Działalność przedsiębiorstw niefinansowych w 2015 r., Warszawa.

Johnston W., Packer A. (1987), Workforce 2000, Hudson Institute, Indianapolis.

Kawka T. (2010), System motywowania kadr menedżerskich w MSP, [w:] M. Matejun (red.), Wyzwania i perspektywy zarzadzania w matych i średnich przedsiębiorstwach, Wydawnictwo C.H. Beck, Warszawa.

Kirton G., Greene A. (2010), The Dynamics of Managing Diversity. A Critical Approach, Butterworth-Heinemann, Oxford-Burlington.

Kufel T. (2011), Ekonometria. Rozwiąywanie problemów z wykorzystaniem programu GRETL, Wydawnictwo Naukowe PWN, Warszawa.

Matejun M. (red.) (2010), Wyzwania i perspektywy zarządzania w matych i średnich przedsiębiorstwach, Wydawnictwo C.H. Beck, Warszawa.

Rak E. (2015), Potrzeba rozwoju pracowników w matych przedsiębiorstwach - wyniki badań, „Management Forum", vol. 3, nr 3, s. 20-27.

Szaban J.M. (2013), Praktyki i dobre praktyki zarzadzania wiekiem w matych i średnich przedsiębiorstwach, „Zarządzanie Zasobami Ludzkimi”, nr 3-4, s. 149-160.

Szepelska A. (2013), Przedsiębiorczość kobiet na tle rozwoju sektora małych i średnich przedsiębiorstw w regionie podlaskim, „Economics and Management” nr 2, s. 139-151.

Urbaniak B. (2014), Zarządzanie różnorodnościa zasobów ludzkich w organizacji, „Zarządzanie Zasobami Ludzkimi", nr 3-4, s. 63-78.

Walczak W. (2011), Zarządzanie różnorodnościa jako podstawa budowania potencjału kapitału ludzkiego organizacji, „E-mentor”, czerwiec, http://www.e-mentor.edu.pl/artykul/index/numer/40/id/840 [dostęp: 7.08.2017]. 
Wziątek-Staśko A. (2012), Diversity management. Narzędzie skutecznego motywowania pracowników, Difin, Warszawa.

Ziemba M., Świerszczak K. (2011), Mechanizm kształtujący wynagrodzenia w podmiotach z sektora MSP w 2008 roku, ,Zeszyty Naukowe Uniwersytetu Szczecińskiego”, nr 685, s. 691-704.

\section{Differentiation of Workers' Primary and Secondary Identity in the Small Enterprises in Poland}

Abstract: The article analyzes the differentiation of selected characteristics of the primary identity (age, sex) and the secondary identity (education, professional experience) of workers employed in the small enterprises in Poland. We extracted data on over 146 thousands workers employed in 7,2 thousands small enterprises out of the individual data base Z-12 (report on structure of wages by occupations). The research shows that within small businesses in Poland the identity of workers varies considerably, especially as regards the secondary one. That diversity is significantly differentiated accordingly to the size and the industry of the employer. Identified instruments of diversity management may help to optimize the human capital also in the small businesses in Poland.

Keywords: diversity management, small enterprises, labour force differentiation

JEL: M14, M54, J82, J24

\begin{tabular}{|l|l|}
\hline \multirow{2}{*}{ OPEN ACCESS } & $\begin{array}{l}\text { C by the author, licensee Łódź University - Łódź University Press, Łódź, Poland. } \\
\text { This article is an open access article distributed under the terms and conditions } \\
\text { of the Creative Commons Attribution license C(-BY } \\
\text { (http://creativecommons.org/licenses/by/3.0/) }\end{array}$ \\
\cline { 2 - 2 } & Received: 2017-04-07; verified: 2017-06-13. Accepted: 2017-11-08 \\
\hline
\end{tabular}

